\title{
Gallbladder adenocarcinoma with human chorionic gonadotropin: a case report and review of literature
}

\author{
Shinkichi Sato*1, Masanori Ishii2 ${ }^{2}$ Takeaki Fujihira² Eisuke Ito² and Yasuo Ohtani²
}

\begin{abstract}
Background: The case of adenocarcinoma with human chorionic gonadtropin (HCG), primary in the male gallbladder, is extremely rare. A Medline search has shown only a few similar cases reported.

Methods: We herein describe a case of primary gallbladder adenocarcinoma associated by ectopic HCG positive tumor cells in a 79-year-old male.

Results: Pathological examination showed a mixture of moderately and poorly differentiated adenocarcinoma with ectopic HCG and placental alkaline phosphatase (PIAP) in tumor cells, though the increase of serum or urinary HCG secretion was not confirmed. The literatures were also reviewed.
\end{abstract}

Conclusions: A case of gallbladder cancer with ectopic HCG production is quite rare in the literature, though many similar cases in other site, especially in Gl tract, are reported. Embryological consideration suggests the increased frequency of similar cases more than being thought now.

\section{Background}

In gallbladder, human chorionic gonadotropin (HCG) related carcinoma is exceedingly rare in the literature. One case of adenocarcinoma with choriocarcinomatous element though negative by immunostain [1], two adenocarcinomas with choriocarcinomatous elements [2,3], one adenosquamous cell carcinoma [4], nine undifferentiated carcinomas [5] and another one extrauterine trophoblastic tumor (ETT) [6] have been reported. In other organs, most of the cases with HCG positive, non-gestational tumors have been reported as non-gestational choriocarcincoma in the gastrointestinal tract such as stomach [7-10], esophagus [11], colon [12,13] and jejunum [14]. Other sites such as brain [15], lung [16,17] and liver [18] have also been reported. In addition to the tumor with choriocarcinomatous elements, ectopic production of HCG by gastrointestinal tract tumors has also been reported by many authors either by using radioimmunoassay [19-22] or by immunohistochemical stain techniques [23-26].

\footnotetext{
* Correspondence: sato@oiso.u-tokai.ac.jp

1 Department of Pathology, Tokai University Oiso Hospital, 21-1 Gakyou, Oiso, Kanagawa 259-0198, Japan

Full list of author information is available at the end of the article
}

Here we report a case of adenocarcinoma with ectopic HCG of the gallbladder. The literatures are also reviewed.

\section{Case report}

A 79-y-old Japanese male was admitted to the Samukawa Hospital (Kanagawa, Japan) because of jaundice in June 2009. Computer tomography (CT) scan and magnetic resonance imaging (MRI) of the abdominal organs showed a mass lesion in the gallbladder, and the obstructive jaundice due to malignancy was suspected. He had no significant past history. Then he was admitted to the Tokai University Oiso Hospital (Kanagawa, Japan) for further examination and surgical treatment. After the additional examinations, clinical diagnosis of gallbladder cancer was made and cholecystectomy was performed at July 7,2009 . No tumorous lesion, suggestive of primary site, was identified in other organ including testis, mediastinum or gastrointestinal tract by CT scan, MRI or other examination.

For light microscopy, the specimen was fixed in $10 \%$ buffered formalin, and $4 \mathrm{~mm}$-thick tissue slices were embedded in paraffin. Paraffin sections were stained with HE. Immunohistochemical detection of various markers 
in tumor was performed by the indirect immunoperoxidase method using antibodies (AE1/AE3; Ventana, HCG; Dako, $\beta$ HCG; Dako, human placental lactogen (HPL); Dako, placental alkaline phosphatase (PlAP); Dako, chromogranin-A (CGA); Dako, CD56; Leika, Insulin; Dako, Glucagon; Dako, Gastrin; Dako, Prolactin; Dako, alfafetoprotein(AFP); Dako, Japan) [27,28].

\section{Pathological Findings}

Pathological examination of the resected gallbladder revealed a large, ulcerative tumor mass measuring $4.5 \mathrm{~cm}$ $\times 3.5 \times 2.5 \mathrm{~cm}$ occupying more than two thirds of the gallbladder wall with necrosis (Fig. 1). Microscopic examinations showed two elements, moderately differentiated tubular adenocarcinoma and rather poorly differentiated lesion with abortive tubular structures (Fig. 2). The tumor invaded through the muscle wall but no extension through the serosa. The TNM stage was T2N0Mo. Residual gallbladder revealed moderate acute and chronic inflammatory cell infiltration and mild to moderate fibrosis in the wall, though neither the features of cholelithiasis nor porcelain gallbladder were evident.

Immunohistochemistry revealed positive staining for cytokeratin AE1/AE3 in all tumor cells, HCG and $\beta$ HCG in the highly atypical tumor cells of poorly differentiated adenocarcinoma (Fig. 3) and for placental alkaline phosphatase (PlAP) in several tumor cells (Fig. 4). Other antigens including HPL, CGA, CD56, insulin, glucagon, gastrin, prolactin and AFP were negative.

Later than one month after the operation, serum HCG titer was measured for the first time and was normal, less than $1 \mathrm{mU} / \mathrm{ml}$. Because of an old male patient with gallbladder tumor, preoperative evaluation of HCG was not performed.

Postoperative chemotheraty with anti-metabolic drug, Gemcitabine hydrochloride, was done and no apparent

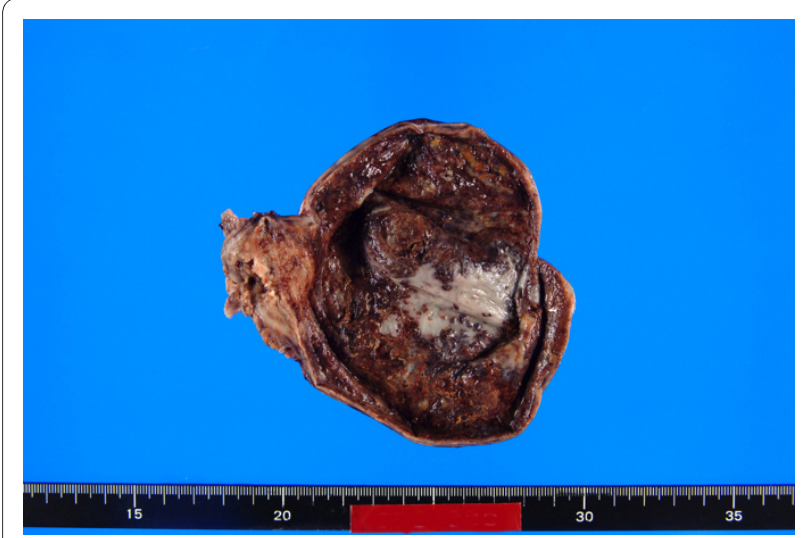

Figure 1 The resected gallbladder with a large, ulcerative tumor mass measuring $4.5 \mathrm{~cm} \times 3.5 \times 2.5 \mathrm{~cm}$ with severe necrotic change.

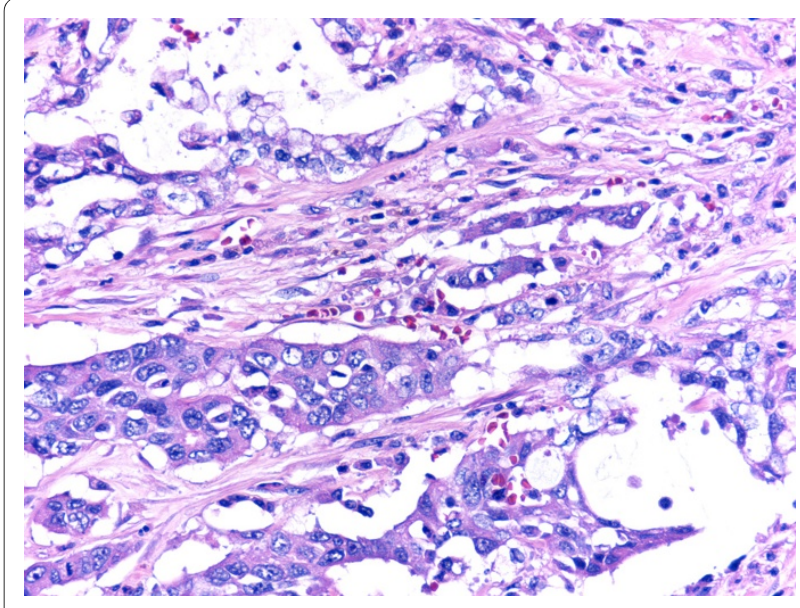

Figure 2 Tumor composed of two elements, moderately differentiated tubular adenocarcinoma (upper one third) and rather poorly differentiated lesion with abortive tubular structures (lower two thirds).

clinical evidence of recurrence has been obtained yet, more than 11 months after the operation.

\section{Discussion}

Although quite rare, some cases of gallbladder carcinoma with HCG have been described in the literatures (Table 1 ). The histological diagnoses of these reports were as follow; choriocarcinoma [1-3], adenosquamous cell carcinoma [4], undifferentiated carcinoma with HCG [5], and extrauterine epithelioid trophoblastic tumour (ETT)[6].

Many cases of non-gestational choriocarcinoma have been reported in gastrointestinal tract or other organs [718 ], though only a few cases were observed in the gallbladder. The case reported as non-gestational, extra-uterine choriocarcinoma, primary in the gallbladder, was first described by Albores-Saavedra and coworkers [1]. The

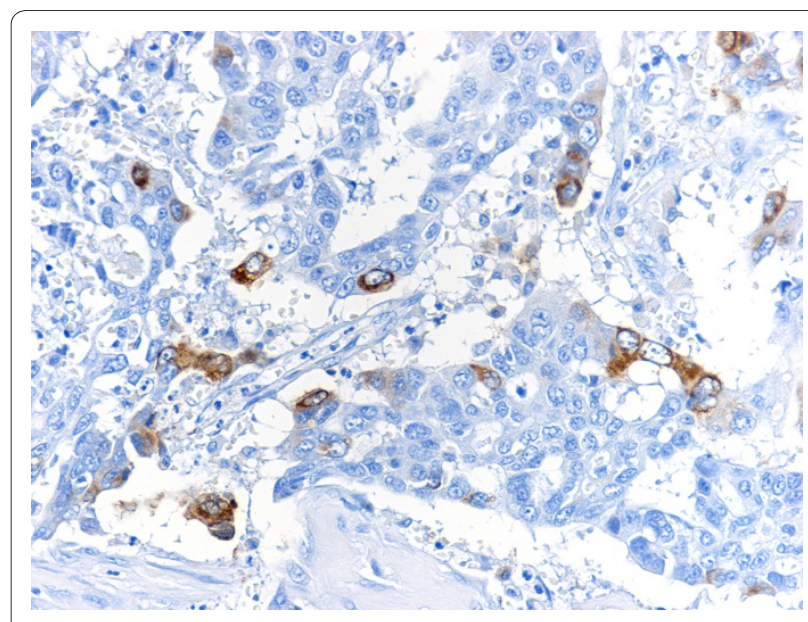

Figure 3 Immunohistochemical staining for $\beta$ HCG in the highly atypical tumor cells of poorly differentiated adenocarcinoma 


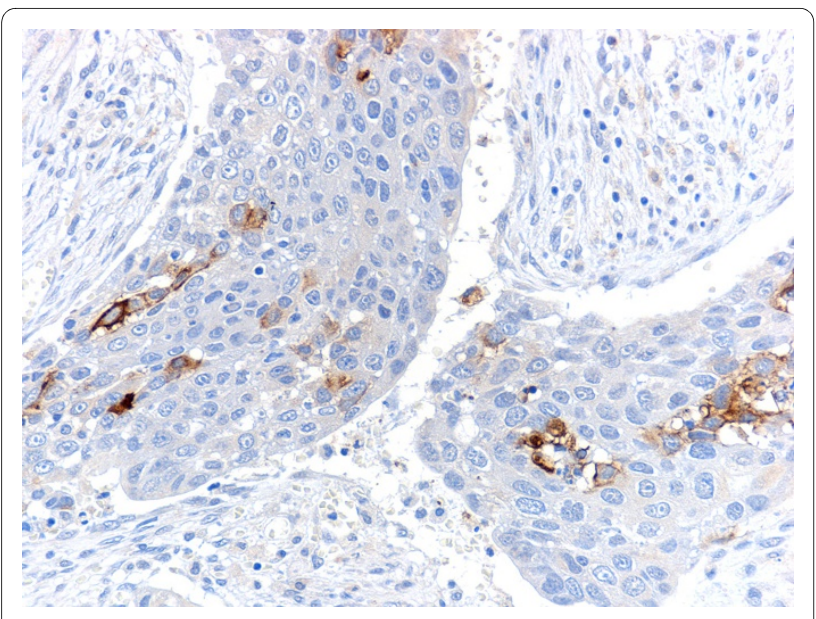

Figure 4 Immunohistochemical staining for placental alkaline phosphatase (PIAP) in several tumor cells.

diagnosis of gallbladder adenocarcinoma with choriocarcinoma-like areas was only made by histological examination, though immunostains for the $\beta \mathrm{HCG}$ were negative and serum or urinary $\beta$ HCG level was not described.

Abu-Farsakh and Fraire represented a second case of coexisting adenocarcinoma and choriocarcinoma of the gallbladder [2]. This may be the first case of such tumor documented by positive immunostaining for the $\beta \mathrm{HCG}$ and the increased levels of serum and urinary $\beta \mathrm{HCG}$, reported in the English language medical literature. Wang and coworkers reported another case of non-gestational choriocarcinoma in gallbladder [3]. This case also represented a mixture of adenocarcinoma and choriocarcinoma.

Fukuda and Ohnishi reported a case of gallbladder adenosquamous cell carcinoma with immunostain positive HCG accompanied by the remarkably increased serum and urinary HCG [4]. The primary lesion in the gallbladder was mainly composed of well differentiated adenocarcinoma and well differentiated squamous cell carcinoma, and metastatic tumor was composed of well to moderately differentiated adenocarcinoma. $\beta \mathrm{HCG}$ positive tumor cells were observed in the adenocarcinoma, especially in poorly differentiated areas.

As in these cases of gallbladder carcinoma, most of the reported cases of non-gestational choriocarcinoma in GI tract or other sites also revealed a coexistent adenocarcinoma component [7-17]. The origin of these choriocarcinomatous elements is still controversial. The various theories regarding pathogenesis include its development from ectopic germ cells or totipotent rests, teratoma, metaplastic differentiation, or metastasis from the intrauterine lesion.

Gastrointestinal tract tumors with ectopic production of HCG have been reported by many authors [19-26].
Fukayama et al reported the immunoreactive HCG in $51 \%$ of 124 cases of gastric carcinoma [23].

In our case, although neither apparent increase of serum or urinary HCG nor histologically typical choriocarcinoma element was confirmed, immunoreactive $\beta$ HCG in adenocarcinoma cells was clearly identified especially in rather poorly differentiated lesion. These findings are consistent with the category, "adenocarcinoma with ectopic production of HCG" and the origin of HCG positive tumor cells in our case might represent a metaplastic differentiation or dedifferentiation.

Guo and coworkers described 21 cases of undifferentiated carcinoma of the gallbladder and $\beta$ HCG positive tumor cells were observed in 9 cases, though serum or urinary level of $\beta$ HCG was not described [5]. Cases were divided into three histological types; small cell type, pleomorphic cell type and spindle cell or pseudosarcomatous type. $\beta$ HCG positive cancers were identified in four out of eight cases in pleomorphic cell type and all of five cases in spindle cell or pseudosarcomatous type tumors. In these nine cases with $\beta$ HCG positive tumor cells, six cases were accompanied by gastrin, somatostatin and/or serotonin positive tumor cells. Authors suggested the neoplastic endocrine cells probably arising by divergent differentiation of the primitive neoplastic cells. These tumors may be categorized in "endocrine cell carcinoma".

Only one case of ETT in the gallbladder with markedly elevated HCG levels in urine and serum was reported in the literature [6]. ETT is a rare condition with approximately 50 reported cases in several organs and originated from cells of intermediate trophoblast. Immunohistochemical stain reveals positive reactions for epithelial markers, HCG and placental alkaline phosphatase, though quite different from our case in histological features.

As previously mentioned, the gastrointestinal tract tumors with ectopic production of HCG have been reported by many authors [19-26] and gallbladder is embryologically originates from the hepatic diverticulum, a ventral outgrowth from the intestine. If sensitive immunohistochemical studies were routinely done in all of gallbladder tumor, the case with immunoreactive HCG might be not a quite rare.

\section{Conclusions}

A case of gallbladder cancer with ectopic HCG production is quite rare in the literature, though many similar cases in other site, especially in GI tract, are reported. Embryological consideration suggests the increased frequency of similar cases more than being thought now.

\section{Consent}

Written informed consent was obtained from the patient for publication of this case report and accompanying 
Table 1: Clinicopathological Summary of Patients with Gallbladder Carcinoma and HCG

\begin{tabular}{|c|c|c|c|c|c|c|c|}
\hline No & Age/sex & Cholelithiasis & $\begin{array}{c}\text { Macroscopic } \\
\text { type }\end{array}$ & Microscopic type & Immunostains & s/u HCG & Ref. No \\
\hline 2 & $29 / F$ & + & Protruded & $\mathrm{AC}+$ Choriocarcinoma & $\operatorname{HCG}(+), \operatorname{AFP}(-), \operatorname{CEA}(-)$ & Elevated & 2 \\
\hline 3 & $48 / F$ & - & Protruded & $\mathrm{AC}+$ Choriocarcinoma & $\mathrm{HCG}(+)$ & Elevated & 3 \\
\hline 4 & $83 / F$ & - & Protruded & ASC & $\mathrm{HCG}(+), \operatorname{AFP}(-), \operatorname{CEA}(+)$ & Elevated & 4 \\
\hline 5 & $68 / F$ & - & Infiltrating & UC, pleomorphic type & $\operatorname{HCG}(+), \operatorname{VIM}(+)$, CEA (+) & ND & 5 \\
\hline 6 & $65 / F$ & + & Protruded & UC, pleomorphic type & $\operatorname{HCG}(+)$, Som $(+), \operatorname{CEA}(+)$ & ND & 5 \\
\hline 7 & $68 / F$ & + & Protruded & UC, pleomorphic type & $\operatorname{HCG}(+), \operatorname{PP}(+), \operatorname{Som}(+)$, Gas $(+)$, CEA (+) & ND & 5 \\
\hline 8 & $68 / F$ & - & Infiltrating & UC, pleomorphic type & $\operatorname{HCG}(+)$, Gas $(+)$, CEA $(+)$ & ND & 5 \\
\hline 9 & $69 / M$ & - & Protruded & UC, spindle cell or ps & $\operatorname{HCG}(+), \operatorname{Vim}(+), \operatorname{Gas}(+), \operatorname{CEA}(+)$ & ND & 5 \\
\hline 10 & $61 / M$ & - & Protruded & UC, spindle cell or ps & $\operatorname{HCG}(+), \operatorname{Vim}(+), \operatorname{Som}(+)$, Gas $(+), \operatorname{CEA}(+)$ & ND & 5 \\
\hline 11 & $66 / M$ & - & Protruded & UC, spindle cell or ps & $\operatorname{HCG}(+), \operatorname{Vim}(+), \operatorname{PP}(+), \mathrm{CEA}(+)$ & ND & 5 \\
\hline 13 & $62 / \mathrm{F}$ & + & Infiltrating & UC, spindle cell or ps & $\begin{array}{l}\text { HCG (+), } \operatorname{Vim}(+), \operatorname{Ser}(+), \operatorname{Som}(+), \text { Gas }(+), \\
\operatorname{CEA}(+)\end{array}$ & ND & 5 \\
\hline 14 & $41 / F$ & ND & ND & ETT & $\operatorname{HCG}(+), \operatorname{PIAP}(+)$ & Elevated & 6 \\
\hline 15 & $79 / M$ & - & Protruded & $A C$ & $\operatorname{HCG}(+), \operatorname{PIAP}(+)$ & NM & * \\
\hline
\end{tabular}

s/u:serum and/or urinary; HCG:human chorionic gonadotropin; AC:adenocarcinoma; ND:not described; AFP:alfa-fetoprotein;

CEA:carcinoembryonic antigen; ASC:adenosquamous cell carcinoma; UC:undifferentiated carcinoma; Vim:vimentin; Som:somatostatin; PP:pancreatic polypeptide; Gas:gastrin; ps:pseudosarcomatous; Ser:serotonin; ETT: extrauterine trophoblastic tumor; PIAP:placental alkaline phosphatase; NM:not measured; *:our case.

images. A copy of the written consent is available for review by the Editor-in-Chief of this journal.

\section{Competing interests}

The authors declare that they have no competing interests.

\section{Authors' contributions}

SS drafted the manuscript and described the pathology component and took photographs, participated in writing the discussion, coordinated and edited the manuscript. MI edited the clinical part of the manuscript. MI, TF, El and YO provided the clinical data and edited the clinical case presentation. SS reviewed the entire manuscript, participated in writing the discussion and the pathology component and edited the manuscript. All authors read and approved the final manuscript.

\section{Author Details}

1Department of Pathology, Tokai University Oiso Hospital, 21-1 Gakyou, Oiso, Kanagawa 259-0198, Japan and 2Department of Surgery, Tokai University Oiso Hospital, 21-1 Gakyou, Oiso, Kanagawa 259-0198, Japan

Received: 8 April 2010 Accepted: 2 July 2010

Published: 2 July 2010

\section{References}

1. Albores-Saavedra J, Cruz-Ortiz H, Alcantara-Vazques A, Henson DE: Unusual types of gallbladder carcinoma. A report of 16 cases. Arch Pathol Lab Med 1981, 105:287-293.

2. Abu-Farsakh H, Fraire AE: Adenocarcinoma and (extragonadal) choriocarcinoma of the gallbladder in young woman. Hum Pathol 1991, 22:614-5. 
3. Wang JC, Angeles S, Chak P, Platt AB, Nimmagadda N: Choriocarcinoma of the gallbladder. Treated with cisplatin-based chemotheratpy. Med Oncol 2001, 18:165-169.

4. Fukuda T, Ohnishi Y: Gallbladder carcinoma producing human chorionic gonadotropin. Am Coll Gastroenterol 1990, 85:1403-6.

5. Guo KJ, Yamaguchi K, Enjoji M: Undifferentiated carcinoma of the gallbladder. A clinicopathologic, histochemical, and immunohistochemical study of 21 patients with a poor prognosis. Cancer 1988, 61(9):1872-9.

6. MacDonald MC, Palmer JE, Hancock BW, Tidy JA: Case report. Diagnostic challenges in extrauterine epithelioid trophoblastic tumours: a report of two cases. Gynecol Oncol 2008, 108(2):452-4.

7. Saigo PE, Brigati DJ, Sternberg SS, Rosen PP, Turnbull AD: Primary gastric choriocarcinoma--an immunohistological study. Am J Surg Pathol 1981, 5:333-342.

8. Jindrak K, Bochetto JF, Alpert LI: Primary gastric choriocarcinoma: case report with review of world literature. Hum Pathol 1976, 7:595-604.

9. Pai MR, Mathai AM, Kumar S, Prabhu S: Coexistent gastric primary choriocarcinoma and adenocarcinoma. Indian J Pathol Microbiol 2009, 52:537-539.

10. Kobayashi A, Hasebe T, Endo Y, Sasaki S, Konishi M, Sugito M, Kinoshita T, Saito N, Ochiai A: Primary gastric choriocarcinoma: Two case reports and a pooled analysis of 53 cases. Gastric Cancer 2005, 8:178-85.

11. McKechnie JC, Fechner RE: Choriocarcinoma and adenocarcinoma of the esophagus with gonadotropin secretion. Cancer 1971, 27:694-702.

12. Park CH, Reid JD: Adenocarcinoma of the colon with choriocarcinoma in its metastases. Cancer 1980, 46:570-575.

13. Kubosawa $\mathrm{H}$, Nagao K, Kondo $\mathrm{Y}$, Ishige $\mathrm{H}$, Inaba N : Coexistence of adenocarcinoma and choriocarcinoma in the sigmoid colon. Cancer 1984, 54:866-868.

14. Soresi AL: Chorioepithelioma of the jejunum. Am J Cancer 1936, 28:583-86.

15. Chan HSL, Humphreys RP, Hendrick EB, Chuang SH, Fitz CR, Becker LE: Primary intracranial choriocarcinoma: a report of two cases and review of the literature. Neurosurg 1984, 15:540-545.

16. Pushchak MJ, Farhi DC: Primary choriocarcinoma of the lung. Arch Pathol Med 1987, 111:477-479.

17. Chen F, Tatsumi A, Numoto S: Combined choriocarcinoma and adenocarcinoma of the lung occurring in a man: case report and review of the literature. Cancer 2000, 91(1):123-9.

18. Shi H, Cao D, Wei L, Sun L, Guo A: Primary choriocarcinoma of the liver: a clinicopathological study of five cases in males. Virchows Arch 2010, 456:65-70.

19. Gailani S, Chu TM, Nussbaum A, Ostrander M, Christoff N: Human chorionic gonadotropins ( $\mathrm{hCG}$ ) in nontrophoblastic neoplasmAssessment of abnormalities of hCG and CEA in bronchogenic and digestive neoplasm. Cancer 1976, 38:1684-1686.

20. Hattori M, Fukase M, Yoshimi H, Matsukura S, Imura H: Ectopic production of human chorionic gonadotropin in malignant tumors. Cancer 1978, 42:2328-2333

21. Papapetrou PD, Sakarelou NP, Braouzi H, Fessas PH: Ectopic production of human chorionic gonadotropin (hCG) by neoplasms--the value of measurements of immunoreactive hCG in the urine as a screening procedure. Cancer 1980, 45:2583-2592.

22. Birkenfeld S, Noiman G, Krispin M, Schwartz S, Zakut H: The incidence and significance of serum $\mathrm{hCG}$ and CEA in patients with gastrointestinal malignant tumors. Eur J Surg Oncol 1987, 15:103-108.

23. Fukayama M, Hayashi Y, Koike M: Human chorionic gonadotropin in gastric carcinoma. Virchows Arch A 1987, 411:205-212.

24. Braunstein GD, Vaitukaitis JL, Carbone PP, Ross GT: Ectopic production of human chorionic gonadotropin by neoplasms. Ann Intern Med 1973, 78:39-45.

25. Ito $\mathrm{H}$, Tahara E: Human chorionic gonadotropin in human gastric carcinoma. Acta Pathol Jpn 1983, 33:287-296.

26. Mori H, Soeda O, Kamano T, Tsunekawa K, Ueda N, Yoshida A, Fukunishi R: Choriocarcinomatous change with immunocytochemically HCGpositive cells in the gastric carcinoma of the males. Virchow Arch A 1982, 396:141-153.

27. Nakane PK, Pierce GB: Enzyme-labelled antibodies: preparation and application for localization of antigens. J Histochem Cytochem 1966 14:929-931.
28. Nakane PK, Pierce GB: Enzyme-labeled antibody for the light and electron microscopic localization of tissue antigens. J Cell Biol 1967, 33:307-318

doi: 10.1186/1746-1596-5-46

Cite this article as: Sato et al., Gallbladder adenocarcinoma with human chorionic gonadotropin: a case report and review of literature Diagnostic Pathology 2010, 5:46

\section{Submit your next manuscript to BioMed Central and take full advantage of:}

- Convenient online submission

- Thorough peer review

- No space constraints or color figure charges

- Immediate publication on acceptance

- Inclusion in PubMed, CAS, Scopus and Google Scholar

- Research which is freely available for redistribution

Submit your manuscript at www.biomedcentral.com/submit
C Biomed Central 